\title{
YOUTH OFFENDING AND YOUTH TRANSITIONS: \\ THE POWER OF CAPITAL IN INFLUENCING CHANGE
}

\author{
Monica Barry \\ Research Fellow, Social Work Research Centre, University of Stirling, Stirling, \\ FK9 4LA, Scotland, UK \\ Tel: 00441786466318 ; fax: 00441786 466319; e-mail: mab2@stir.ac.uk
}

\begin{abstract}
Neither the literature on offending nor that on desistance adequately explains the short-term nature of youth offending, young people's propensity to desist from offending as they reach early adulthood and the importance of youth transitions in helping or hindering young people's access to legitimate and conventional opportunities and responsibilities. It is suggested in this article that the three phases of offending - onset, maintenance and desistance - run parallel courses with the three phases of youth transitions -childhood, youth and adulthood and that both these processes are influenced by discrepancies in levels of capital for young people at each stage. In a recent Scottish study of desistance, Bourdieu's concepts of capital are used to demonstrate the commonalities between youth offending and youth transitions and to better understand young people's search for integration and recognition - whether this be through offending or conventionality. The article concludes that the concepts of capital and youth transitions could both be employed more usefully in the field of criminology to explain the transient nature of offending in youth and the greater likelihood of desistance once legitimate and sustainable opportunities are found to spend as well as to accumulate capital in early adulthood.
\end{abstract}




\section{INTRODUCTION}

Young people's aspirations towards conventionality and mainstream goals are factors often ignored by both academics and policy makers in attempting to understand youth offending (MacDonald, 1997). Policy, research and practice tend to problematize and sensationalize youthful criminal activity, and focus on the perpetrator rather than the cause. However, many young people by dint of their age, but also because of disadvantaged backgrounds, are restricted by structural constraints in the transition to adulthood, notably in relation to their legal status as young adults as well as their opportunities for further education and employment (Furlong and Cartmel, 1997, Wyn and White, 1997). The importance of social inequalities and social institutions in determining or undermining youth transitions is becoming increasingly apparent. Many young people are excluded from higher education (through a lack of qualifications or financial support), from employment opportunities and from housing. Nevertheless, the fact is that the majority of young people who are marginalized or otherwise disadvantaged within the labour market as elsewhere do not rebel against their predicament. On the contrary: 'The response of the unemployed to the aggravation of labour market disadvantage lies not in the development of some highly distinctive subculture, but in the reinforcement of more conventional working-class beliefs' (Gallie, 1994: 756, quoted in MacDonald, 1997: 175).

This article draws on findings from a recent study which examined young people's views and experiences of offending and desistance in order to understand the wider 
problems they face which offending may well have been masking as well as manifesting. The research also explored whether offending behavior demonstrated a need for, rather than a rebellion against, social integration. This article concludes that young people indeed want to conform rather than to rebel and may, ironically, use offending in the otherwise liminal phase of youth as a means of integration. Concepts of capital are drawn on, notably Bourdieu's $(1984 ; 1986)$, to demonstrate how young people can, on the one hand, gain kudos and recognition in youth through offending but also, on the other hand, find legitimate and conventional means of accumulating and spending capital as they move into early adulthood. First, however, the article summarizes the gaps in existing theories of offending and desistance before exploring the potential of models of capital and youth transition as a means of better understanding youth offending as a temporary, age-related process of change at a time of relative powerlessness in the transition to adulthood.

\section{UNDERSTANDING YOUTH OFFENDING AND DESISTANCE IN THEORY}

There is often an overlap between individual, structural and cultural explanations as to why people commit crimes. Much criminological literature suggests that young people in particular offend for one or more of a wide variety of reasons: because of their age; through rational choice for utilitarian, economic or hedonistic gain; because of an inability to achieve one's aspirations within society; as a result of a lack of selfcontrol; because of the influence of others; because of enjoyment and cultural 'lifestyles'; or because of a lack of socialization (Barry, 2006). In addition to these 
individual, structural and cultural forces, there is a further school of thought, namely that offending behavior is ubiquitous and normal but that it may be socially or politically labelled as a problem so as to ensure and justify social control.

Theories of crime and criminality are varied and wide-ranging, not least because of the multi-disciplinary nature of criminology. Within the sociological discourse on criminology, there is also the dichotomy between micro- and macro-sociological stances. Farrall and Bowling (1999: 261), for example, have described much of the criminological literature as being split between seeing individuals as 'super-agents' or as 'super-dupes'. The former are free to make their own decisions about what they do, and the latter are restricted by the influences and determinants of external forces. Few theories of offending can explain young women's involvement in crime, the gendered nature of law enforcement practices and changes or reductions in seriousness or frequency. Equally, they cannot readily explain why some offenders do not desist from crime in adulthood: offenders are as likely to be influenced by significant others and events in deciding to continue offending as they are in deciding to stop.

Whilst much of the criminological literature on offending could be criticized for not being able to account for why many people are not involved in crime in the first place or why the majority of offenders stop, equally much of the desistance literature is not premised on any assumptions about why young people start offending, focusing only on the factors inhibiting or fostering desistance, irrespective of the antecedents to such behavior. Desistance is not an easily measurable phenomenon, not least because of the 
difficulty of identifying when desistance has been successful (Farrall, 2000; Farrington, 1986; Shover, 1996). Studies of desistance have not readily differentiated between what has been termed 'life-course persistent' and 'adolescent-limited' offending (Moffitt, 1993), where there may be a diverse range of factors differentiating the two types of offender. Equally, relatively few studies have looked at desistance from a feminist criminological perspective or have included the specific experiences of female offenders (Carlen and Worrall, 1987). Although Jamieson et al. (1999) suggest that young women report similar types of offending as their male counterparts, they also suggest that young women find it easier to desist from offending than young men (see also Graham and Bowling, 1995). Whilst the desistance literature increasingly seeks the views of offenders and ex-offenders themselves, thus combining micro-level structural factors (such as access to employment or family relationships) with individual narratives (Maruna, 2001). Such literature tends to avoid the need to address the macro-level structural constraints and imbalances within society (including poverty, responsibility and human rights issues). Nor do desistance studies necessarily address the fact that not all offenders actually desist for the reasons generally advocated in that literature.

Thus, much of the literature on desistance is set apart from that on offending and ignores the possibility of offending and desistance as two dimensions of a process of change over time and space. However, some theories of offending have suggested potential commonalities with those of desistance. In particular, Gottfredson and Hirschi's (1990) theory of self-control offers the potential to explain both onset and desistance in parallel, as does Rational Choice Theory (Cornish and Clarke, 1986) and 
Matza's (1964) theory of drift. Indeed, Bottoms et al. (2004) have appropriated Matza's theoretical framework in a recent study of desistance in the UK. However, desistance in many such theories is seen more as a negation or absence of the original problems that caused offending to start, rather than being seen as part of a proactive process of change. In addition, these particular theories are not strong in explaining how that change might take place, only that it may.

Such a diagnosis of the problem, which basically sees onset and desistance as two discrete topics of academic interest, is perhaps unhelpful in understanding offending and desistance as a process of change for the individual. As criminological theory currently stands, there seems to be a lack of congruence and continuity between those factors influencing onset and those influencing desistance. On the one hand, sociocultural as well as individual determinants tend to be seen as most influential in young people's propensity to start offending, but, on the other hand, socio-cultural determinants tend not to be seen as influential in young people's desistance from offending. Whilst political correlates (if not causes) are associated with onset, regrettably no such political 'solutions' are offered in the desistance literature, placing the emphasis more on the individual to reduce or stop offending. MacDonald and Marsh (2005), amongst others, suggest that youth transitions have become more individualized, resulting in a greater tendency for young people to blame themselves for their own predicaments. Narrative theory tends to exacerbate this 'epistemological fallacy' (Furlong and Cartmel, 1997: 114). McNeill (2006: 46), for example, suggests that desistance is 'a wider process that belongs to the desister', based on subjective identity change. Equally, Bottoms et al. (2004) emphasize individual agency and 
cognitive reorientation. However, this article argues that such an emphasis on agency is unhelpful if it is at the expense of structural and political factors which may well constrain young people in the transition to adulthood. The wider society needs to be as proactive, agency-wise, in providing and maintaining meaningful opportunities for young people in the transition to adulthood.

\section{THE AGE OF TRANSITION}

To examine offending as a process of change for young people, it seems imperative to explore the position of young people in society more generally, their transitional experiences from childhood, through youth to adulthood and their relative lack of durable and legitimate capital during that transitional phase. For example, given the emphasis within the desistance literature on employment and relationships as a turning point in stopping offending (Shover, 1996), a parallel investigation of transitions (where employment and relationships are two key components) would also seem pertinent. Likewise, the widening debate over the need to combine agency and structure in the criminological literature (Farrall \& Bowling, 1999) has commonalities with more recent youth transitions research (Stephen \& Squires, 2003). Several authors have recently argued for criminology to accommodate youth transitions research (for example, Bottoms et al., 2004; MacDonald and Marsh, 2005), as MacDonald and Marsh (2005: 172) comment: "It would be difficult to comprehend an individual criminal career without also considering concurrent, wider experiences of 
transition not normally surveyed in criminology". However, to date, such an accommodation within criminology has not been forthcoming in any systematic way.

Nevertheless, the discipline of anthropology can offer helpful links between youth transitions and powerlessness which may inform criminological thinking. Certain anthropologists in the 1960s, for example, examined the experiences of adolescents in small-scale societies and the 'rites of passage' that they progress through in preparation for adulthood. Whilst the term 'youth' was not seen as a middle phase between childhood and adulthood in such anthropological studies, Van Gennep (1960, cited in Turner, 1967) nevertheless identified three elements in the transition from childhood to adulthood in terms of 'rites of passage', namely, separation, margin and aggregation (Turner, 1967). Whilst Van Gennep focused on the more positive aspects of 'ritual' and 'ceremony' for young people in making the transition to adulthood, his middle 'liminal' phase (margin) has been adapted to emphasize the more negative interpretations of youth which have been usurped by governments to restrict or forestall their movements as full citizens (Barry, 2006). Turner (1969) describes individuals within the liminal phase as: "persons or principles that (1) fall in the interstices of social structure, (2) are on its margins, or (3) occupy its lowest rungs' (ibid: 125). For small-scale traditional societies, liminality was a planned-for stage pending a 'new beginning' (Turner, 1967; 1969), even though Turner suggests that 'transitional beings...have nothing. They have no status, property, insignia, secular clothing, rank, kinship, position, nothing to demarcate them structurally from their fellows' (Turner, 1967: 98-99). For many disadvantaged young people in Britain 
today, however, this phase of the lifecycle holds no status and there are few supportive structures to guide them through the transition to adulthood.

As mentioned above, research on youth transitions has been used relatively sparsely in the field of criminology, but it is argued here that such research and theorising can provide a better understanding of youth offending as perceived and experienced by young people. Studying youth transitions in parallel with youth offending enables an exploration of the influence of age, power and integration in the transition to full citizenship in adulthood. Childhood and youth are phases in the lifecycle where the individual is denied access to the capital enjoyed by adults. Offending can bring alternative sources of capital as well as temporary relief from an otherwise disempowering milieu. The paucity of capital afforded young people in transition can, to a certain extent, be offset by the potential capital they can gain from offending in that period. The following section highlights the means by which young people can access capital through offending and demonstrates their need in the longer term for more durable and legitimate ways to both accumulate and spend capital.

\section{BRIDGING THE GAP: THE POWER OF CAPITAL}

The term 'capital' tends to be used in relation to assets (mainly economic), although also implies advantage, and more recently has been used to denote more a political struggle for scarce, finite and unequally distributed 'power'. There are now many 
forms of capital drawn upon in sociological circles, the most common of which is social capital. This has been used not only by Bourdieu (1984) but has been given more recent prominence by both Coleman (1988) and Putnam (2000). Coleman includes obligations, trust, expectations, norms and information-sharing in his description of social capital. Because he sees it as an inherently rational and utilitarian tool within communities, he also sees social capital as being potentially harmful and able to be discarded at will. Putnam (2000) also suggests a 'dark side' to social capital when he acknowledges that it can be adversarial as well as consensual. Putnam stresses the 'sense of belonging' within communities and engagement in voluntary activity. He differentiates 'bonding' from 'bridging' social capital, with the former being within close-knit groups and the latter being between looser group structures. MacDonald and Marsh (2005: 203), in a recent study of young people's transitions in disadvantaged communities, talk of 'the paradox of networks', where such communities are seen as lacking bridging social capital, and whilst they may have strong sources of bonding social capital, they can only 'get by' rather than 'get on' with such restricted sources of capital.

For young people, 'Putnamesque' social capital is a confining and often irrelevant concept, not least where it pertains to civic participation and geographically-defined community networks. As Morrow (2001:54) argues: "For children and young people, 'community' is more often a 'virtual' community of friends based around school, town centre and street, friends' and relatives' houses, and sometimes homes in two different towns, rather than a tightly-bound easily-identifiable geographical location". 
Whereas both Coleman and Putnam stress the more communitarian aspects of social capital within an institutionalized context, Bourdieu focuses on power relationships and the inevitability of the unequal distribution of capital amongst different groups and societies. Bourdieu is principally interested in the relational context of everyday actions and perceptions: the struggle for identification and recognition (Bourdieu, 1989), a major source of which is capital. He suggests that individual and collective constructions of the social world are not developed in a vacuum but are reproduced by, and themselves reproduce, social structures and are thus subjected to structural constraints. There is a constant interplay between structural constraints and individual choice, and the importance of time, space, agency and the individual's capacity to change are all implicated in the construction and reconstruction of the social world. Bourdieu's concept of capital is thus, it is argued, better placed to understand young people's position in the transition to adulthood. Bourdieu (1984) identifies four forms of capital - social, cultural, economic and symbolic - which are described briefly below:

Social capital is valued relations with significant others and is generated through relationships which in turn bring resources from networks and group membership. To Bourdieu, social capital includes not only social networks but also 'sociability' - 'a continuous series of exchanges in which recognition is endlessly affirmed' (1986: 250). For young people, the accumulation of social capital is less stable by dint of their transitional status. Whilst for many, the family is the main source of social capital, social relationships are also developed within the school milieu, although these 'friendships' tend to lack continuity over time. Nevertheless, social capital 
gained within the peer group is a crucial source of temporary support and recognition for young people in transition.

Economic capital is the financial means to not only the necessities but also the luxuries of everyday living, including inheritance, income and assets. Economic capital is not a major source of capital for young people generally, given their transient status between childhood and adulthood, their confinement to full-time education and their resulting segregation from the adult labour market, although it is acknowledged that young people from middle class backgrounds will be able to draw more readily on the economic and other capitals accruing from their families. For many young people from disadvantaged backgrounds, crime is often the only alternative source of economic capital to employment.

Cultural capital is legitimate competence, qualifications or status and comes from knowledge of one's cultural identity in the form of art and education in particular. It can include styles and modes of presentation and identity; consumables and other cultural goods; and educational and other qualifications or status. To Bourdieu, cultural capital is not easily acquired or transmitted and is seen as an established form of capital that only truly gains legitimacy over time and via institutionalized or objectified means. It does not lend itself readily, therefore, to the relatively short (in terms of the life cycle) transition period between childhood and adulthood. However, the concept of cultural capital is increasingly being adopted in relation to the 
commodification of youth and young people's unique cultural identities (MacRae, 2002; Skeggs, 1997).

Symbolic capital is an overarching resource that brings prestige and honour gained from the collective, legitimate and recognized culmination of the other three forms of capital: 'the power granted to those who have obtained sufficient recognition to be in a position to impose recognition' (Bourdieu: 1989: 23) It is recognition which is primarily accrued through 'services, gifts, attention, care, affection' (Bourdieu, 1991: 128). For young people, symbolic capital often results from successful offending: having a positive reputation amongst one's offending peers and 'street credibility' and particularly for young men, can be a crucial source of social and self identity within the peer group.

According to Bourdieu, capital of whatever kind takes time and effort to both accumulate and transmit and therefore has to be both durable and legitimate in order to withstand structural constraints over time. Whilst these forms of capital can be a viable and vital source of identity, status, recognition, reputation and power within the immediate friendship group in the short term, it is argued here that for working class youth in particular, they are not durable or legitimate in the eyes of the wider society because of the paucity of opportunities available to many young people in transition. Young people, by dint of their status as 'transitional beings' (Turner, 1967: 98) and especially those from working class backgrounds, tend to have few, if any, fixed or permanent obligations towards, responsibilities for, or expectations of, gaining capital 
beyond their immediate environment of friends and family. It is thus crucial to explore youth offending in parallel with youth transitions in order to understand the extent to which young people can gain capital in youth through offending and the extent to which their sources and levels of capital can change over time. The following section describes some of the findings from the author's recent study of youth offending which demonstrates the potential of offending for accessing capital in childhood and youth and the alternative, more conventional sources of such capital that are available to young people as they move into early adulthood.

\section{UNDERSTANDING OFFENDING AND DESISTANCE IN PRACTICE}

In a recent Scottish study (Barry, 2006), twenty men and twenty women aged 18-33 were interviewed in depth about their experiences and views of starting and stopping offending. The study aimed to explore the factors that influence or inhibit offending behavior, from the perspective of both young men and young women, and to assess any common denominators between the process of starting, continuing and stopping offending. The young people were contacted via both a national intensive probation project and social work departments. All were persistent offenders in the past (the men had a mean average of 24 previous convictions and the women 12) and two thirds of the sample stated at interview that they had stopped offending. Interviews tended to be conducted in people's own homes (although six were interviewed in prison) and lasted on average one and a half hours. Issues covered at interview included definitions, type and frequency of offending; reasons, advantages, 
disadvantages and circumstances surrounding starting, continuing and stopping offending; factors which helped and hindered both starting and stopping offending; the impact of external factors on offending behavior; and future aspirations. The views and experiences of these young people as they move through the transition to adulthood and towards desistance are briefly explored below. The significance of capital, and young people's variable access to it, is demonstrated concurrently with these phases of transition.

\section{Childhood/onset}

According to the findings from this study, offending in childhood could be seen as a means of gaining capital within the friendship group when other sources of capital are either dissipating (through a distancing from the family unit) or changing (through the entrance into an adult-led and authoritarian school environment or through the development of an individual and social identity). Either way, children from disadvantaged backgrounds or those lacking confidence or emotional support, may well feel vulnerable in such changed circumstances and if offending proves successful in accumulating more, or sustaining existing, capital, such behavior is likely to be continued, not least if alternative sources of capital are elusive, denied or rejected.

All the young people in this study came from disadvantaged backgrounds and were generally adversely affected by family upheaval, a lack of stability and continuity in 
childhood and limited opportunities for love, attention and encouragement in the transition to adulthood. Eighteen of the 20 men and 14 of the 20 women suggested they had started offending under the age of 15 and the majority said they started offending as a means of social integration (through 'buying' friends or acquiring consumer goods). Friends, irrespective of whether or not they were offending, were a crucial source of social capital as these young people moved away from the influence of the family and into the school environment. Having a reputation as an offender also gave them symbolic capital. The women in particular were more likely to start offending specifically for the attention of usually a male partner who was offending, because this gave them social and symbolic capital, as one 23 year old woman suggested:

[My first boyfriend] was a drug dealer and I admired him... I fancied him and I thought he was cool because everybody respected him and all the people my age respected me because I was mucking about with this person (23 year old woman).

The perceived outcomes of offending were both economic and sociable at first, and it could be argued that economic gain is in itself a means towards integration with others. Offending offered possible status and identity in moving from the confines of the family into the wider social network of the school milieu: 
I was looking for, I suppose in a way, folk to look at me in a different light, for folk to think of me differently - to fit in, in a way... and to be noticed... I had to make friends because I was alone... to me [offending] was my only escape (19 year old man).

Gender differences in the onset phase were quite pronounced, with the men tending to start offending earlier for reasons more to do with economic or personal gain (e.g., excitement) and the women starting later for reasons more to do with sociability (for attention, to 'buy friends' or because of a fear of reprisals for not 'fitting in'). Although sociability and relationships were the main impetus for the young women starting offending, they were also much more likely than the men to see the additional economic advantages of offending (for consumables, clothes and drugs), whereas the men were more likely to see the personal advantages of relieving boredom and keeping in with one's friends.

The women were also more likely to be influenced to take drugs by male partners who were themselves using drugs - not least if those partners wanted the women to help them raise the money to feed a drug habit. This often resulted in the women becoming not only dependent on drugs but also dependent on those relationships with drugusing partners for love and attention, however violent they became: 
I got forced into it. Basically my boyfriend turned round and said do you love me? I said aye, I love you. He said, if you love me, try this. I said I don't want to. And he said he'd batter me if I didn't (21 year old female).

\section{Youth/maintenance}

In youth, offending became more of a 'chore' or economic necessity rather than a valued source of attention and friendship; and yet youth is a time when young people possibly lack or reject attention, protection or encouragement from family and the wider community. Youth is the phase when young people have few socially recognized means of legitimating their stake in the social world but may see offending or its benefits as their only means of gaining recognition meantime, even if such recognition comes only from other offending friends or resultant consumables.

When comparing the reasons, costs and benefits of offending in the maintenance phase with those of the onset phase, the study highlights the importance of differentiating between the two phases. This study is relatively innovative in this respect, when judged against the theoretical input on crime and criminality which rarely examines changes in attitudes, behavior and justifications of offending over the course of an offending history. Most of the sample overall seemed dissatisfied with their offending behavior over time, either because it no longer gave them what they wanted in terms of friends, money or status, or because they became increasingly wary of the consequences of their actions. Sociability and status over time were 
superseded by necessity, resignation or addiction. Reasons for continuing to offend tended to revolve around a drug habit or a desire for, or expectation of, supplementary income and other forms of capital:

[Shoplifting] gave me confidence. I felt going with somebody else's cheque book and getting all dressed up and going in [to a shop], I could spend what I wanted, they treated me well because they thought I had enough money. They had a different outlook... It was like a power trip (29 year old woman).

... the shoplifting, that was mostly for drugs. I used to shoplift for myself to begin with, you know, just wee things for myself, then I started doing it as a business where I was shoplifting every day to make money (26 year old man).

Realization of what they had to lose or the 'hassle factor' also became stronger over time, as did responsibilities towards family members, partners, children or one's own tenancy. In this latter respect, the women seemed to have acquired greater responsibilities at a younger age than their male counterparts, thus questioning sooner for them the value of continuing to offend:

It was 18 months I was away from my son. He cried at every single [prison] visit... And I just thought I can't do this any more. I can't do that... I can't do any more to him (33 year old woman). 
Whilst a positive reputation amongst one's peers was often an incentive to start offending, this was increasingly offset by a negative reputation within their wider social network (both in the family and the community) as they became involved with the criminal justice system in the maintenance phase. Many suggested in retrospect that they knew they were almost immune from punishment under the age of 16 , when in the UK young people leave a welfare-oriented system of youth justice and enter the more punitive adult criminal justice system. But beyond the age of 16 , these young people became disillusioned and disempowered by the police, the courts, custody and a criminal record. One young man epitomized the view of many when he explained: 'I'm sick of the jail, sick of it. I'm too well known by the police. They stop and question me for no reason and people judge me" (23 year old man).

\section{Adulthood/desistance}

Offending may have brought capital initially, but the majority realized in early adulthood that the capital gained from offending was short-lived and eventually created more hassle for them than going straight. Only when offending is seen to have more social costs than personal benefits will young people attempt to reduce their offending so as to adapt to their current social situation. In early adulthood, the criminal justice system tends to erode what little capital accumulation young people can gain from offending or indeed from conventional activities or relationships: 
When I was at court one day and I got the probation, I just sat down on my arse and thought: do you give it up or do you do it, because one day you will get the jail and get the kids took off you and it's not worth it. OK you've not got all the nice clothes you did have, and you've not got the money. I can do without things like that just now. I can focus on getting to... the point where I can go out and get a job and get another bit of my life done instead of stealing (20 year old female).

Nevertheless, opportunities for renewed family contact, relationships with conventional partners and employment or other forms of legitimate income and responsibility can be a major source of capital accumulation for those young people who manage to escape the confines of the criminal justice system.

'Criminal justice system fatigue' was a commonly stated reason for wanting to stop offending, coupled with a realization of what they increasingly had to lose by continuing to offend. And yet the eight men and five women who had not stopped offending at the time of interview had above-average previous convictions and tended to have had longer criminal histories. However, of those who had stopped offending (12 men and 15 women), whilst they may have drifted into it, the majority made proactive decisions to stop, irrespective of the lack of positive incentives available to them. Thus, there were few perceived 'pull' factors involved in their decision to stop offending, with the criminal justice system, a drug addiction, loss of trust within the 
family and a deteriorating reputation being the main 'push' factors. At the time of stopping offending, the majority did not have employment or a stable relationship, often seen by desistance theorists as the main catalysts to desistance. However, some of the respondents were encouraged in their decision to desist by having the support of friends, family, children and law-abiding partners:

... having a son. Once he was born, then I really put the foot down... Because I had someone else I had to look out for other than myself... my son, he was too young to look after himself. That's my job (24 year old man).

[My fiancé] brought a really different side out on me. He makes me relaxed, more calmer, and it's like as if I found someone who really cares and actually is interested in me for who I really was (25 year old woman).

\section{DISCUSSION}

Generally, desistance for the women resulted more from actual commitments to children, partners or parents, whereas for the men desistance was more in preparation for potential commitments (for example, aspirations towards employment or raising a family). Byrne and Trew (2005) support these findings in suggesting that young men have more positive orientations towards crime than young women, in that the former see offending as rewarding, exciting and sociable: an end in itself. Young women, on 
the other hand, see offending as pragmatic and financially necessary: a means to an end. Much criminological theory, notably that developed by cultural criminologists in recent years, fails to unpick these gender differences in offending and desistance namely that young women rarely enjoy the 'thrills and spills of edgework' (Presdee, 2000: 62) at any point in the process of offending/desistance, and that for young men, the novelty of starting offending soon wears off as routine or necessity take over (Barry, 2006).

In this study, it was implied by many respondents that their propensity to offend or not offend was very much based on their need both for integration and for a semblance of control or power over their own lives. Few criminological theories have specifically focused on disparities of power, opportunity and participation for young people in the transition to adulthood and yet the findings from this study highlight the relevance of Bourdieu's concepts of capital, for two reasons. First, young people's reasons for starting, continuing and stopping offending revolved around issues of friendships, money, reputation and kudos. These issues can equally be transferred into the four concepts of capital espoused by Bourdieu - social, economic, cultural and symbolic. Secondly, it became apparent during the course of analysis that the three phases of offending tended to coincide with the three phases of transition, thus exemplifying the 'age-crime curve'. Whilst this latter concept tends to be used to demonstrate maturation, this study suggests that the age-crime curve better signifies a balance - or more exactly, an imbalance - of power rather than maturation per se. The sources of capital available to these young people between the three 
phases of offending changed in quality and quantity as they got older and as other commitments came to the fore in early adulthood.

What is often missing from such analyses, however, is an answer to the question of how capital in its various forms can reduce the likelihood of offending when such capital can be gained from offending itself. The answer may lie in the concept of 'social recognition' (Barry, 2006), where a combination of expenditure and accumulation of capital is necessary not only in the transition to adulthood but also in the transition to desistance. What was particularly striking about the young people's narratives in the study cited above was their emphasis on taking on responsibilities for others and wanting to give back to others for the damage or hurt they had caused in the past, however indirectly. This suggested that the accumulation of capital is not enough to encourage desistance from crime, but that young people need to have opportunities for the expenditure of capital also. Expenditure of capital means giving something back to others through one's own actions. The two main ways this can be achieved for young people are through taking on responsibilities ${ }^{1}$ and 'generativity, ${ }^{2}$ (Maruna, 2001). Obvious examples of responsibility-taking would be having employment, or having responsibility for one's own children or family:

I've got responsibility to myself, to keep myself out of trouble and off drugs and I've got my baby on its way. I've got a responsibility towards [my partner] as well... Attend probation, hospital, lawyers (27 year old woman) 
[I want to] make sure that [my daughter] gets the things that I never got in life, like a good home, steady family, mother and father to care for her, good schooling, you know (28 year old man).

Examples of generativity would be wanting to become a drugs counsellor or probation worker (because of one's own positive experiences of such workers in the past); wanting to ensure that their own children have a better life than they had; and wanting to make restitution to the local community for past offending:

I want to be an instructor for an outward bound course. I want to put into the community what I've taken from it. I want to do courses with under-privileged kids like myself (28 year old man).

[I want to] get a really good job in the social work or something like that... I get on with the younger ones up here and I try and say to them: 'don't do what I done, stop taking [drugs] because it ruins everything' (23 year old woman)

In this study, it seemed that those who had desisted from crime were more likely to have opportunities for responsibility-taking and generativity than those who were still persistent offenders. In this respect, there were pronounced differences between the young men and young women in the sample. For the young women, opportunities to 
take on responsibilities for themselves or others were more readily accessible to them because of their expectations of a caring role (with parents, partners, younger siblings or their own children). The findings from this study support Jamieson et al's (1999) suggestion that women find it easier to desist from offending than men, and it is argued here that this is because women have greater access to opportunities to spend as well as to accumulate capital in the transition to adulthood. Generativity and responsibility-taking were more pertinent to the collective and emotional approach of women (Gilligan, 1982), as mothers and partners, whereas the men had reduced opportunities for accumulating and spending capital via legitimate means.

Whilst capital accumulation is a crucial factor in aiding both desistance and a smoother transition to adulthood, the added factor of capital expenditure is required to ensure that young people have the opportunity and incentive to desist from crime as well as the longer-term opportunities afforded their counterparts in adulthood. Whilst many of the desisters in the study cited were still in the transition phase of youth, they seemed to have already found or been given opportunities to spend as well as to accumulate capital. Social recognition may well be a helpful concept in understanding desistance amongst young people in transition because it expresses the capacity and need that young people have for longer-term reciprocal relations of trust and responsibility within the wider society.

\section{CONCLUSIONS}


It has been suggested here that a combination of expenditure and accumulation of capital is necessary not only in the transition to adulthood but also in the transition to desistance. Young people are less likely to offend if they have durable and legitimate opportunities to take on responsibilities and to offer their skills and support to others. However, for varying reasons, such opportunities are unlikely to become available in the childhood and youth phases of transition, which is when the temporary accumulation of capital through offending has more tangible benefits. This study suggests that persisters - as well as young men more generally - lacked opportunities for expenditure of capital through conventional means and experienced more constraints than desisters in the transition to adulthood. However, those who managed to stop offending seemed to have greater opportunities for expenditure of capital. Indeed, the majority of desisters in the Scottish study stated at interview that they were not experiencing current difficulties in their lives and that they could readily identify responsibilities that they had to significant others.

It would therefore seem plausible that offending and desistance are not correlated with age so much as with levels of responsibility, durability and legitimacy. Indeed, the factors most often associated with adulthood - stable employment or one's own home and family - were not achieved in the majority of cases, irrespective of the age at which the respondents stopped offending. This suggests that there are other factors affecting one's propensity or otherwise to stop offending rather than age or adulthood per se, and this is where Bourdieu's concept of capital accumulation and its suggested counterpart, expenditure, come to the fore. 
Sampson and Laub (1993) suggest that the maturational reform approach within criminology has focused on adolescents in a vacuum, divorced from their origins as children and from their ultimate destination as adults. Equally, the political implications of 'youth' and 'youth transitions', given that they are distinctive but nevertheless temporary phenomena, have not featured largely in the criminological literature on offending and desistance. This is seen as regrettable given the close association between offending, desistance and age and the fact that much youth offending follows a similar course as the so-called transition to adulthood. This makes youth transitions a pertinent concept for further investigation within criminology. As a heuristic device, the concept of youth transitions is crucial to an understanding of desistance, not least because of the age-crime curve. The processes of offending and transition tend to run parallel courses, which could be argued to reflect not only age but also levels of capital accumulation and expenditure. Young people from disadvantaged backgrounds in particular have limited access to capital to ease the transition to adulthood; but they also need and want to experiment, to interact with others, to be respected and to achieve eventual recognition and inclusion within the wider society.

However, durability and legitimacy of capital - crucial factors in the achievement of social recognition - are not readily accessible within the youth phase, as this phase is seen as transient and lacking in legitimate and sustained opportunities for young people. Whilst offending in youth can increase one's short-term accumulation of capital, it is unlikely to address the need for expenditure of capital or for longer-term, sustainable capital accumulation. However, once young people have access to durable 
and legitimate opportunities for responsibility-taking and generativity, thereby developing opportunities for expenditure of capital as well as accumulation, it is more likely that desistance will occur. Thus the concept of capital is perhaps better able to explain the transient nature of offending in youth and the likelihood of desistance once legitimate opportunities are available in early adulthood to both accumulate and spend such capital.

\footnotetext{
${ }^{1}$ The term 'taking on responsibilities' in this context should not be confused with 'responsibilization', often cited in relation to restorative justice and the need for offenders to be confronted, challenged and held responsible for their actions (Raynor, 2004).

${ }^{2}$ The term 'generativity' here means having the desire to care for others and to feel needed through productive and intergenerational outlets. Maruna (2001) cites a typology of generativity by Stewart et al. (1988) which includes caring for others; making a lasting contribution; concern for one's offspring; being needed; and productivity/growth.
}

\section{REFERENCES}

Barry, M. (2006) Youth Offending in Transition: The search of social recognition, Abingdon: Routledge.

Bottoms, A., Shapland, J., Costello, A., Holmes, D. and Muir, G. (2004) 'Towards

Desistance: Theoretical Underpinnings for an Empirical Study', The Howard Journal, Vol. 43, 4: 368-389. 
Bourdieu, P. (1984) Distinction: A Social Critique of the Judgement of Taste, London: Routledge.

Bourdieu, P. (1986) 'The Forms of Capital' in J. G. Richardson (Ed), Handbook of Theory and Research for the Sociology of Education, Westport, CT: Greenwood Press.

Bourdieu, P. (1989) 'Social Space and Symbolic Power', Sociological Theory, 7: 1425.

Bourdieu, P (1991) Language and Symbolic Power, edited and introduced by J.B. Thompson, translated by G. Raymond and M. Adamson, Cambridge: Polity Press. Byrne, C. and Trew, K. (2005) 'Crime Orientations, Social Relations and Involvement in Crime: Patterns Emerging from Offenders' Accounts, The Howard Journal of Criminal Justice, 44, 2: 185-205.

Carlen, P. and Worrall, A. (eds) (1987) Gender, Crime and Justice, Milton Keynes: Open University Press.

Coleman, J.S. (1988) 'Social Capital in the Creation of Human Capital', American Journal of Sociology, 94, supplement S95-S120.

Cornish, D. and Clarke, R.V. (1986) The Reasoning Criminal, New York: SpringerVerlag.

Farrall, S. (Ed) (2000) The Termination of Criminal Careers, Aldershot: Ashgate. 
Farrall, S. and Bowling, B. (1999) 'Structuration, Human Development and

Desistance from Crime' in British Journal of Criminology, Vol. 39, No. 2: 253-268.

Farrington, D. (1986) 'Stepping stones to adult criminal careers', in D. Olweus, J.

Blackand and M.R. Yarrow (eds), Development of antisocial and prosocial

behaviour, New York: Academic Press.

Furlong, A. and Cartmel, F. (1997) Young People and Social Change:

Individualization and Risk in Late Modernity, Milton Keynes: Open University Press.

Gilligan, C. (1982) In a Different Voice: Psychological Theory and Women's

Development, Cambridge, MA: Harvard University Press.

Gottfredson, M. and Hirschi, T. (1990) A General Theory of Crime, Stanford, CA:

Stanford University Press.

Graham, J. and Bowling, B. (1995) Young People and Crime, London: Home Office.

Jamieson, J., McIvor, G. and Murray, C. (1999) Understanding Offending Among

Young People, Edinburgh: The Stationery Office.

MacDonald, R. (1997) 'Youth, social exclusion and the millennium' in R. MacDonald

(Ed), Youth, the 'underclass' and social exclusion, London: Routledge.

MacDonald R. and Marsh, J. (2005) Disconnected Youth? Growing Up in Britain's

Poor Neighbourhoods, Basingstoke: Palgrave Macmillan. 
McNeill, F. (2006) 'A desistance paradigm for offender management', Criminology and Criminal Justice, Vol. 6(1): 39-62.

MacRae, R. (2002) Becoming a Clubber: Transitions, Identities and Lifestyles, unpublished $\mathrm{PhD}$ thesis, Stirling: University of Stirling.

Maruna, S. (2001) Making Good: How ex-convicts reform and rebuild their lives, Washington DC, American Psychological Association.

Matza, D. (1964) Delinquency and Drift, New York: Wiley.

Moffitt, T.E. (1993) Adolescence-limited and life-course-persistent antisocial behavior: A developmental Taxonomy, in Psychological Review, 100: 674-701.

Morrow, V. (2001) 'Young people's explanations and experiences of social exclusion: retrieving Bourdieu's concept of social capital', International Journal of Sociology and Social Policy, Vol. 21, No. 4/5/6: 37-63.

Presdee, M. (2000) Cultural Criminology and the Carnival of Crime, London: Routledge.

Putnam, R.D. (2000) Bowling alone: the collapse and revival of American community, New York: Simon and Schuster.

Raynor, P. (2004) 'Opportunity, motivation and change: some findings from research on resettlement', in R. Burnett and C. Roberts (eds) What Works in Probation and Youth Justice: Developing evidence-based practice, Cullompton: Willan. 
Sampson, R.J. and Laub, J.H. (1993) Crime in the Making: Pathways and turning points through life, Cambridge, MA: Harvard University Press.

Shover, N. (1996) Great Pretenders: Pursuits and Careers of Persistent Thieves, Boulder, CO, Westview Press.

Skeggs, B. (1997) Formations of Class and Gender: Becoming respectable, London: Sage.

Stephen, D. and Squires, P. (2003) “'Adults don’t realize how sheltered they are': A contribution to the debate on youth transitions from some voices on the margins', Journal of Youth Studies, Vol. 6, No. 2, June: 145-164.

Stewart, A. J., Franz, C. and Layton, L. (1988) 'The changing self: Using personal documents to study lives', in Journal of Personality, 56: 41-74.

Turner, V. (1967) The Forest of Symbols: Aspects of Ndombu ritual, Ithaca, NY:

Cornell University Press.

Turner, V. (1969) The Ritual Process: Structure and Anti-Structure, Chicago: Aldine.

Wyn, J. and White, R. (1997) Rethinking Youth, London: Sage. 